\title{
Wpływ warunków wykonania napoin na własności stali ARMOX 370T w obszarze wokół napoiny
}

\author{
Influence of the tack weld welding conditions \\ on ARMOX 370T steel properties in the weld area
}

\section{Streszczenie}

Przedstawiono zmianę rozkładu twardości stali ulepszanej cieplnie (pancernej) ARMOX 370T Class 2 w obszarze napoiny wykonanej metodą MAG drutem SG2 oraz drutem G18 8 Mn. W przeprowadzonych eksperymentach napoiny reprezentują różne klasy spoin sczepnych zarówno pomiędzy elementami z tego samego materiału, jak i spoiny sczepne pomiędzy elementami wykonanymi ze stali ARMOX 370T Class 2, a przyrządami usztywniającymi i montażowymi wykonanymi ze stali konstrukcyjnej. Zmiennymi parametrami procesu napawania były: temperatura podgrzewania wstępnego, rodzaj materiału dodatkowego, długość napoiny oraz energia liniowa napawania. Monitorowano także parametry spawania. Wykonane napoiny poddano ocenie wizualnej, badaniom metalograficznym makroskopowym i mikroskopowym oraz zbadano rozkład twardości w obszarze napoin. Wyniki badań wskazały, że w celu ograniczenia twardości w obszarze wokół napoiny (spoiny sczepnej) jej długość powinna wynosić co najmniej $25 \mathrm{~mm}$. Podgrzewanie wstępne do napawania i stosowania niskiej energii liniowej napawania także powoduje obniżenie twardości w materiale rodzimym wokół napoiny (spoiny sczepnej). Gatunek zastosowanego drutu nie wpływa na maksymalne wartości twardości w obszarze napoiny.

Słowa kluczowe: stal pancerna; Armox 370T; spoina sczepna; rozkład twardości

\begin{abstract}
The article presents the change in the distribution of hardness of ARMOX 370T Class 2 steel in the area around the bead on plate weld made by GMA SG2 wire and $\mathrm{G} 188 \mathrm{Mn}$ wire. In the experiments welds represent different classes of tack welds between elements of the same material and tack welds between elements made of steel ARMOX 370 T Class 2 and the stiffening and mounting devices made of structural steel. Welding variable were: preheat temperature, type of filler metal, length of weld and heat input. Welding parameters were monitoring during the welding. Tack welds were examined visually and cross section of welds were observed on microscope at macro and micro magnification. Also hardness distribution in the area around weld was tested. Results of tests show that the length of bead on plate (tack weld) should be at least $25 \mathrm{~mm}$ to keep the hardness in acceptable limits. Preheating and low heat input in also results in lowering the hardness in the base metal near weld. Type of welding wire does not influence the maximum value of hardness in the area of weld.
\end{abstract}

Keywords: armoured steel; Armox 370T; tack weld; hardness distribution

\section{Wstęp}

Nieustanne zapotrzebowanie na produkty o coraz lepszych własnościach mechanicznych, eksploatacyjnych i technologicznych wymusza stały rozwój materiałów na konstrukcje spawane. Postęp, jaki dokonał się w ostatnich latach pozwolił opracować nowe gatunki stali ulepszanych cieplnie, które to wykorzystywane, jako główny materiał konstrukcyjny pozwalają projektować, budować coraz większe i bardziej skomplikowane konstrukcje spawane.

Stale ulepszane cieplnie przeznaczone na konstrukcje spawane są materiałami o bardzo dużej wytrzymałości

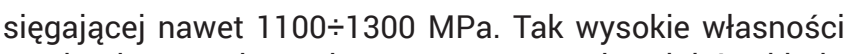
mechaniczne osiąga się poprzez precyzyjny dobór składu chemicznego stali oraz hartowanie i odpuszczanie od temperatury walcowania. Konstrukcyjne stale ulepszane cieplnie zawierają kombinację pierwiastki stopowych poprawiających hartowność np. chrom, molibden, bor i pierwiastków zapewniających drobnoziarnistą strukturę stali z wydzieleniami. Kombinacja ta zapewnia wysoką wytrzymałość przy stosunkowo wysokich własnościach plastycznych oraz dobrej spawalności, pomimo podwyższonej skłonności do pęknięć zimnych w strefie wpływu ciepła, a także często w spoinach. Niskowodorowe procesy spawania i podgrzewanie

Dr hab. inż. Krzysztof Luksa, prof. PŚl., mgr inż. Rafał Olbrich - Politechnika Śląska, mgr inż. Marek Bednarek - ROSOMAK S.A. Siemianowice Śląskie. 
wstępne do spawania są na ogół zalecane przez producentów tych stali, zwłaszcza dla większych grubości blach [1,2,3]. Stale ulepszane cieplnie są często wykorzystywane do budowy konstrukcji o dużej masie własnej, takich jak mosty, zbiorniki, cysterny, suwnice, a specjalne gatunki tych stali zapewniają dobrą odporność balistyczną elementów kadłubów i pancerzy pojazdów wojskowych lub specjalnych. Ze względu na pogorszenie się własności materiału podczas spawania umiejętne dobranie warunków procesu, podział na podzespoły i odpowiednia kolejności wykonania spoin, minimalizują negatywny wpływ spawania na konstrukcję i efekcie uzyskuje się wyrób lub złącze o pożądanych własnościach. Z uwagi na stosunkowo krótki okres obecności tych stali na rynku, prowadzone są ciągle badania wpływu procesu spawania na własności materiału tych blach $[4,5]$.

\section{Wcześniejsze badania}

Badania spawalności stali ulepszanych cieplnie prowadzone w ostatnich latach pozwoliły wypracować szereg warunków technologicznych procesu spawania. Rezultaty uzyskane przez $[1,6]$ pozwoliły określić, że dla spoiw ferrytycznych do spawania wymagane jest podgrzewanie wstępne do temp. $75 \div 200{ }^{\circ} \mathrm{C}$ w zależności od grubości elementu czy blachy. Temperatura ta powinna być utrzymywana przez cały czas trwania procesu. Dla spoiw austenitycznych wystarczająca jest temp. $18 \div 20^{\circ} \mathrm{C}$ (pokojowa), jednak dla grubości elementu powyżej $30 \mathrm{~mm}$ wskazane jest podgrzewanie wstępne do temp. maksymalnie $200{ }^{\circ} \mathrm{C}$. Stosowanie właściwych spoiw do spawania stali ulepszonych cieplnie jest bardzo istotne, gdyż jak podaje [7] stale te są podatne na pękanie zimne, a zakres temperatur podgrzewania wstępnego jest niewielki. Wysokie temperatury spoin i konieczność kontrolowanego ich chłodzenia generuje wiele problemów, stąd konieczność wprowadzenia odpowiednich składników stopowych niereagujących z wodorem. Pozwala to zmniejszyć zawartości wodoru dyfundującego do strefy wpływu ciepła, a tym samym ograniczyć ryzyko pęknięć związanych z kruchością wodorową [14].

Istotnym czynnikiem jest wspomniane już podgrzewanie wstępne. Wyższa temperatura początkowa spawanego elementu pozwala zmniejszyć szybkość chłodzenia całego złącza, a przez to w stalach ulepszanych cieplnie strefa wpływu ciepła nie ulega znacznemu podhartowaniu. Badania prowadzone przez producentów stali Armox dowiodły, że maksymalna temperatura podgrzewania wstępnego powinna wynosić $200{ }^{\circ} \mathrm{C}$ [8]. Jako optymalną temperaturę podgrzewania wstępnego dla stali ulepszonych cieplnie wg. [9] ustalono na ok. $190^{\circ} \mathrm{C}$. W przeprowadzonych pomiarach twardości strefy wpływu ciepła wybranych stali twardość nie przekroczyła 400HV. Prowadzono także badania nad procesem sczepiania blach. Spoiny sczepne są ważnym elementem procesu wytwarzania zapewniając poprawne ustawienie względem siebie spawanych płyt i ograniczenie odkształceń wykonywanej konstrukcji. W przypadku, gdy w spoinie sczepnej wystąpiło pęknięcie należy je niezwłocznie usunąć i wykonać nową spoinę sczepną. Wykonane prawidłowo spoiny sczepne, po przetopieniu stanowią integralną część złącza, dlatego zaleca się wykonywanie ich we właściwej kolejności, aby generowały jak najmniejsze naprężenia łączonych blach [10]. Dodatkowo, jeśli grubości elementów przekraczają $25 \mathrm{~mm}$ wskazane jest wykonywać je w dwóch lub więcej przejściach z minimalną energią liniową spawania. Ponadto doświadczenia wykazały, że istotną jest także długość spoiny sczepnej [8]. Producent w przypadku stali Armox podał minimalną długość spoiny sczepnej równą ok. $50 \mathrm{~mm}$, co uzasadnił optymalnymi warunkami chłodzenia złącza i niewielkim ryzykiem wystąpienia pęknięć zimnych. Dla większości stali ulepszanych cieplnie długości spoin sczepnych powinna mieścić się w przedziale $25 \div 50 \mathrm{~mm}$ [11]. Znaczna liczba badań związanych z aspektami technicznymi wykonywania złączy w stalach ulepszanych cieplnie pozwoliła opracować zalecenia technologiczne dla ich procesu spawania zwłaszcza, że ciepło spawania niekorzystnie wpływa na spawany materiał, pogarszając jego własności i strukturę.

\section{Cel i zakres badań}

Celem poznawczym niniejszych badań jest wyznaczenie optymalnych warunków wykonania krótkich spoin/napoin na stalach konstrukcyjnych ulepszanych cieplnie. Struktura stali ulepszanych cieplnie jest wrażliwa na nagrzewanie związane z procesem spawania, które zazwyczaj prowadzi do pogorszenia własności tego obszaru, a w skrajnych warunkach zwiększenia jego skłonności do pęknięć zimnych. Zjawisko to występuje zwłaszcza przy wykonywaniu krótkich spoin/napoin, ponieważ pole temperatur nie jest ustabilizowane, a szybkie odprowadzenie ciepła z tego obszaru powoduje, że szybkość stygnięcia może być znacznie wyższa niż przy wykonywaniu „długich spoin”. Oszacowana zostanie także "krytyczna" długość napoiny, poniżej której można się spodziewać wzrostu twardości w obszarze wokół spoiny. Wzrost twardości w obszarze spoiny/napoiny jest niekorzystny ze względów spawalniczych, jednak ze względów eksploatacyjnych niekorzystne jest także obniżenie twardości w obszarze spoiny/napoiny. Szczególne zastosowanie stali ARMOX 370T Class 2 na konstrukcje narażone na obciążenia udarowe (wybuchy) powoduje, że jeżeli obszar obniżonej twardości będzie zbyt duży podzespół spawany może utracić wymagane własności eksploatacyjne.

Badania przeprowadzono na stali ARMOX 370T Class 2. Na próbkach wykonano napoiny metodą MAG. Warunki nagrzewania i stygnięcia napoin są zbliżone do warunków cieplnych występujących przy wykonywaniu spoin sczepnych złączy doczołowych i podobne do warunków cieplnych występujących przy wykonywaniu niektórych spoin mocujących przyrządy montażowe i usztywniające. Jako zmienne warunki wykonania napoin przyjęto energię liniową spawania, temperaturę podgrzewania wstępnego, skład chemiczny materiału dodatkowego oraz długość napoiny. Dla każdej z wykonanych napoin przeprowadzono badania twardości oraz badania metalograficzne makroskopowe i mikroskopowe.

Tablica I. Skład chemiczny stali ARMOX 370T Class $2[8,12,13]$

Table I. Chemical composition of ARMOX 370T class 2 steel $[8,12,13]$

\begin{tabular}{|c|c|c|c|c|c|c|c|c|c|}
\hline \multirow{2}{*}{ Gatunek stali } & \multicolumn{8}{|c|}{ Skład chemiczny [zawartość maks. w \%] } \\
\cline { 2 - 10 } & $\mathrm{C}$ & $\mathrm{Si}$ & $\mathrm{Mn}$ & $\mathrm{Ni}$ & $\mathrm{P}$ & $\mathrm{S}$ & $\mathrm{Cr}$ & $\mathrm{Mo}$ & $\mathrm{B}$ \\
\hline $\begin{array}{c}\text { ARMOX 370T } \\
\text { Class 2 }\end{array}$ & 0,32 & 0,4 & 1,2 & 1,8 & 0,015 & 0,010 & 1,0 & 0,7 & 0,005 \\
\hline
\end{tabular}

CEV dla ARMOX 370T Class 2 wynosi $0,67 \div 0,75$ 
Tablica II. Własności mechaniczne stali ARMOX 370T Class $2[12,13]$

Table II. Mechanical properties of ARMOX 370T Class 2 steel [12,13]

\begin{tabular}{|c|c|c|c|c|c|c|c|}
\hline \multirow{2}{*}{$\begin{array}{c}\text { Gatunek } \\
\text { materiału }\end{array}$} & $\begin{array}{c}\text { Grubości } \\
\text { blach [mm] }\end{array}$ & $\begin{array}{c}\text { Twardość } \\
{[\mathrm{HB}]}\end{array}$ & $\begin{array}{c}\text { Granica } \\
\text { plastyczności } \\
\mathrm{R}_{\mathrm{p} 0.2}[\mathrm{MPa}]\end{array}$ & $\begin{array}{c}\text { Wytrzymałość } \\
\text { na rozciąganie } \\
\mathrm{R}_{\mathrm{m}} \text { min [MPa] }\end{array}$ & $\begin{array}{c}\text { Praca łamania } \\
\text { KV [J] }\end{array}$ & $\begin{array}{c}\text { Wydłużenie } \\
\mathrm{A}_{5} \text { min [\%] }\end{array}$ & $\begin{array}{c}\text { Wydłużenie } \\
\mathrm{A}_{50} \text { min [\%] }\end{array}$ \\
\hline $\begin{array}{c}\text { ARMOX 370T } \\
\text { Class 2 }\end{array}$ & $6 \div 60$ & $280 \div 330$ & 800 & $900 \div 1100$ & $40\left(-40^{\circ} \mathrm{C}\right)$ & 13 & 15 \\
\hline
\end{tabular}

Tablica III. Parametry wykonania napoin na stali Armox 370T Class 2

Table III. Welding parameters of test welds completed on ARMOX 370T Class 2 steel

\begin{tabular}{|c|c|c|c|c|c|c|c|}
\hline \multicolumn{8}{|c|}{ Parametry wykonania napoin } \\
\hline \multirow{2}{*}{ Ip. } & \multirow{2}{*}{ Gatunek drutu } & \multirow{2}{*}{$\begin{array}{c}\text { Temperatura } \\
\text { podgrzewania } \\
\text { wstępnego } \\
{\left[{ }^{\circ} \mathrm{C}\right]}\end{array}$} & \multirow{2}{*}{$\begin{array}{l}\text { Długość } \\
\text { napoiny } \\
\text { [mm] }\end{array}$} & \multicolumn{2}{|c|}{$\begin{array}{c}\text { Zarejestrowane parametry } \\
\text { napawania }\end{array}$} & \multirow{2}{*}{$\begin{array}{c}\text { Prędkość } \\
\text { spawania } \\
\text { [mm/s] }\end{array}$} & \multirow{2}{*}{$\begin{array}{c}\text { Energia } \\
\text { liniowa } \\
{[\mathrm{kJ} / \mathrm{mm}]}\end{array}$} \\
\hline & & & & $\begin{array}{l}\text { Natężenie prądu } \\
\text { [A] }\end{array}$ & $\begin{array}{l}\text { Napięcie łuku } \\
\text { [V] }\end{array}$ & & \\
\hline 1 & SG2 & BRAK & 12,5 & 212,7 & 26,6 & 5 & 0,9 \\
\hline 2 & SG2 & BRAK & 25 & 216,7 & 24,6 & 5 & 0,9 \\
\hline 3 & SG2 & BRAK & 50 & 214,3 & 24,4 & 5 & 0,9 \\
\hline 4 & SG2 & BRAK & 75 & 214,3 & 24,2 & 5 & 0,9 \\
\hline 5 & SG2 & 150 & 12,5 & 208,3 & 26,6 & 5 & 0,9 \\
\hline 6 & SG2 & 150 & 25 & 208,1 & 25,6 & 5 & 0,9 \\
\hline 7 & SG2 & 150 & 50 & 212,3 & 24,5 & 5 & 0,9 \\
\hline 8 & SG2 & 150 & 75 & 213,5 & 24,2 & 5 & 0,9 \\
\hline 9 & CastoMag45554S & BRAK & 12,5 & 193,4 & 25,7 & 5 & 0,8 \\
\hline 10 & CastoMag45554S & BRAK & 12,5 & 241,8 & 32,1 & 4 & 1,5 \\
\hline 11 & CastoMag45554S & BRAK & 50 & 198 & 25 & 5 & 0,8 \\
\hline 12 & CastoMag45554S & BRAK & 50 & 241 & 31,8 & 4 & 1,5 \\
\hline 13 & CastoMag45554S & 150 & 12,5 & 195,2 & 25,1 & 5 & 0,8 \\
\hline 14 & CastoMag45554S & 150 & 12,5 & 232,2 & 32,9 & 4 & 1,5 \\
\hline 15 & CastoMag45554S & 150 & 50 & 177,6 & 23,6 & 5 & 0,8 \\
\hline 16 & CastoMag45554S & 150 & 50 & 234,5 & 31,8 & 4 & 1,5 \\
\hline
\end{tabular}

\section{Badane materiały}

Jako materiał podstawowy zastosowano stal konstrukcyjną ulepszaną cieplnie ARMOX 370T Class 2 o grubości $14 \mathrm{~mm}$. Stal ta wykorzystywana jest do budowy konstrukcji, od których wymaga się specjalnych własności, np. wysokiej odporność na obciążenia udarowe. W zastosowaniach cywilnych wykorzystywana w konstrukcjach o wysokiej odporności na obciążenia dynamiczne. Skład chemiczny badanej stali zestawiono w tablicy I [8,12,13], natomiast własności przedstawiono $\mathrm{w}$ tablicy II $[12,13]$.

\section{Wykonane eksperymenty}

Napoiny wykonano metodą MAG na zrobotyzowanym stanowisku spawalniczym wyposażonym w robota REIS SRV6 i urządzenie spawalnicze TotalArc2 5000. Jako gaz osłonowy wykorzystano mieszankę wg PN-EN ISO 14175: M21 $\left(80 \% \mathrm{Ar}+20 \% \mathrm{CO}_{2}\right)$. Jako materiał dodatkowy zastosowano druty PN-EN ISO 14341: G3Si1 (SG2) i drut austenityczny PN-EN 12072: G18 8 Mn (CastoMag 45554S) o średnicy 1,2 $\mathrm{mm}$. W czasie napawania rejestrowano napięcie i natężenie prądu spawania rejestratorem parametrów spawania RPS-2.

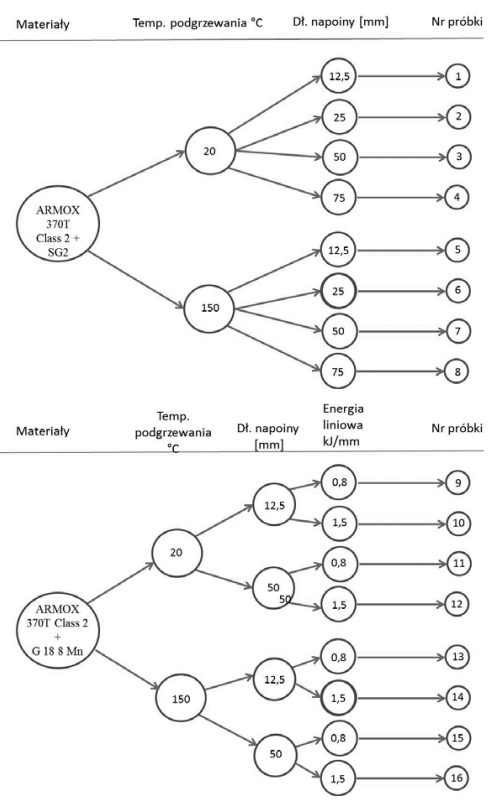

Rys. 1. Plan badań dla napoin wykonanych drutem SG2 i drutem G18 $8 \mathrm{Mn}$ na stali ARMOX 370T Class 2

Fig. 1. The plan of experiments for welds made SG2 wire and wire G18 $8 \mathrm{Mn}$ on ARMOX 370T Class 2 steel 
Eksperymenty wykonano zgodnie z planem przedstawionym na rysunku 1 . Wstępna analiza wyników badań napoin wykonanych drutem SG2 spowodowała, że ograniczono liczbę długości napoin wykonanych drutem G18 8 Mn i wprowadzono dodatkowy parametr - energię liniową spawania - rysunek 1. Szczegółowe parametry wykonania każdej próbki zestawiono w tablicy III. Napięcie i natężenie prądu spawania zamieszczone $w$ tablicy III są uśrednionym parametrami pochodzącymi z rejestratora parametrów spawania RPS2.

\section{Badania wizualne wykonanych napoin}

Wykonane napoiny poddano ocenie wizualnej. Badano formowanie napoiny i obecność niezgodności możliwych do wykrycia w badaniach wizualnych. Nie stwierdzono obecności niezgodności, rysunki 2 i 3.

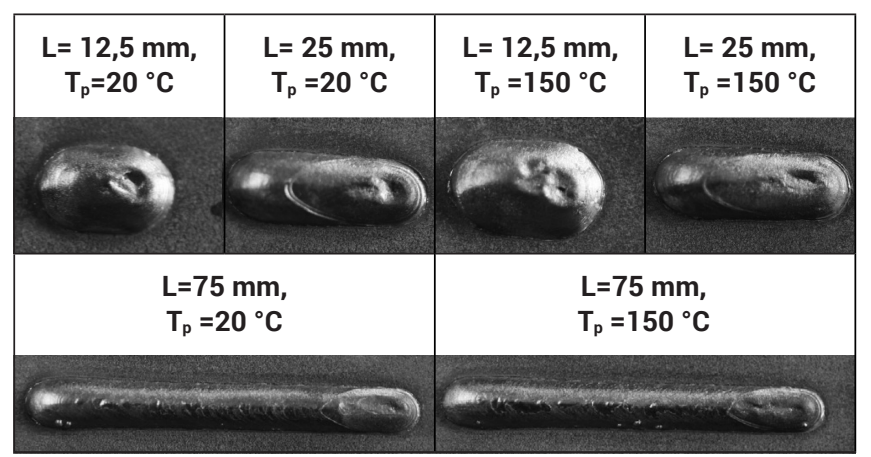

Rys. 2. Widok lica napoin wykonanych metodą MAG, drutem SG2 w osłonie gazowej M21,na blasze ze stali ARMOX 370T Class 2. L - długość napoiny, $T_{p}$ - temperatura podgrzewania wstępnego Fig. 2. Face view of MAG made welds. Wire SG2, gas-shielded M21, plate ARMOX 370T Class 2

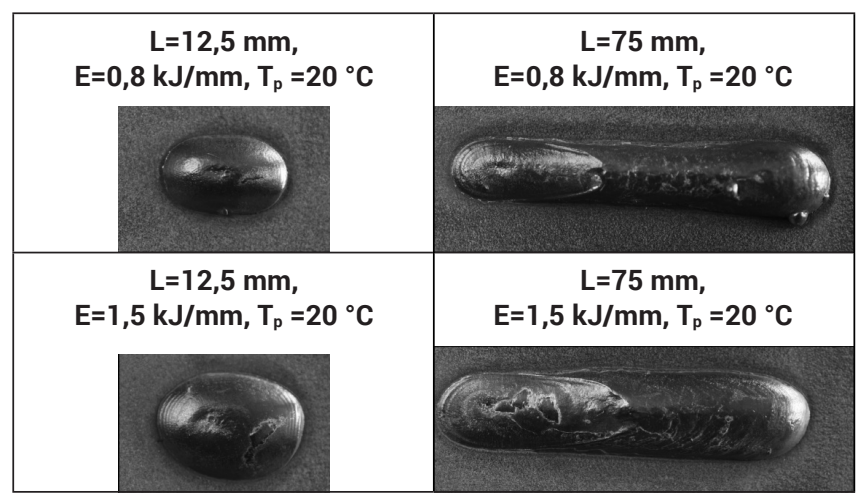

Rys. 3. Widok lica napoin wykonanych metodą MAG, drutem G 188 $\mathrm{Mn}$ w osłonie gazowej M21, na blasze ze stali ARMOX 370T Class $2 \mathrm{~L}$ - długość napoiny, $T_{p}$ - temperatura podgrzewania wstępnego Fig. 3. Face view of MAG made welds. Wire SG2, gas-shielded M21, plate ARMOX 370T Class 2
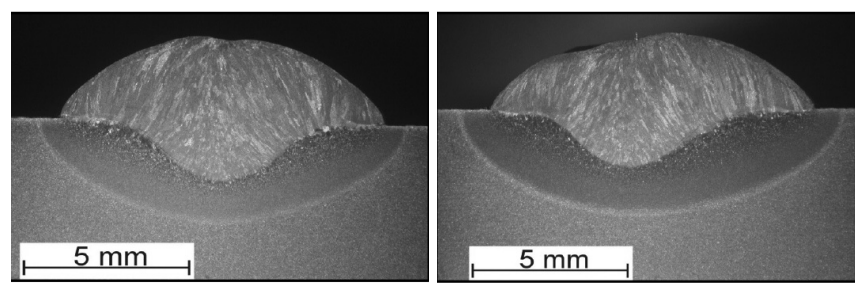

Rys. 4. Makrostruktura przekroju poprzecznego napoin o długości $12.5 \mathrm{~mm}$ wykonanych drutem SG2 na stali Armox 370T Class 2 bez podgrzewania wstępnego (lewa strona) i z podgrzewaniem wstępnym (prawa strona)

Fig. 4. Macrostructure in cross-section of welds with a length of $12.5 \mathrm{~mm}$ made of steel wire SG2 on Armox 370T Class 2 without preheating (left side) and preheating (right)

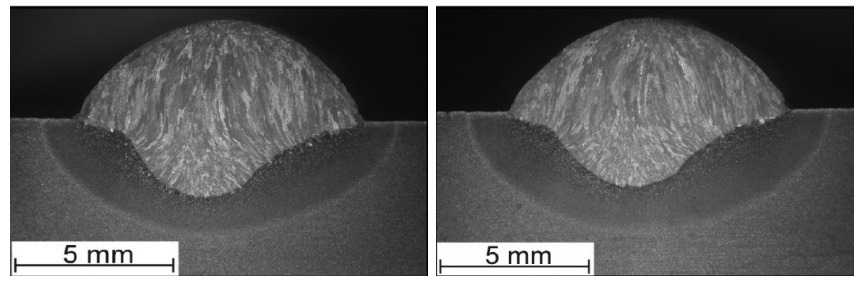

Rys. 5. Makrostruktura przekroju poprzecznego napoin o długości $75 \mathrm{~mm}$ wykonanych drutem SG2 na stali Armox 370T Class 2 bez podgrzewania wstępnego (lewa strona) i z podgrzewaniem wstępnym (prawa strona)

Fig. 5. Macrostructure in cross-section of welds with a length of 75 mm made of steel wire SG2 on Armox 370T Class 2 without preheating (left side) and preheating (right)
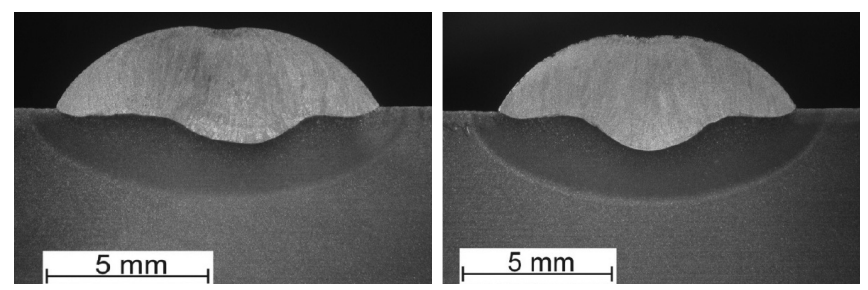

Rys. 6. Makrostruktura przekroju poprzecznego napoin o długości 12,5 mm wykonanych drutem G18 $8 \mathrm{Mn}$ na stali Armox 370T Class 2 bez podgrzewania wstępnego $\mathrm{E}=0,8 \mathrm{~kJ} / \mathrm{mm}$ (lewa strona) i $\mathrm{E}=1,5$ $\mathrm{kJ} / \mathrm{mm}$ (prawa strona)

Fig. 6. Macrostructure in cross-section of welds with a length of $12.5 \mathrm{~mm}$ made of steel wire G18 8 on Armox 370 T Class 2 without preheating $E=0.8 \mathrm{~kJ} / \mathrm{mm}$ (left side) and $E=1.5 \mathrm{~kJ} / \mathrm{mm}$ (right)
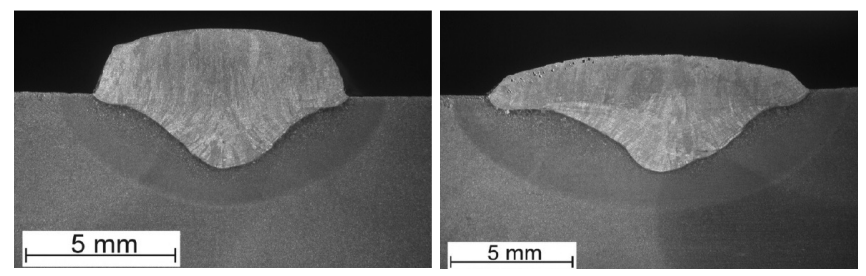

Rys. 7. Makrostruktura przekroju poprzecznego napoin o długości $50 \mathrm{~mm}$ wykonanych drutem G18 $8 \mathrm{Mn}$ na stali Armox 370T Class 2 bez podgrzewania wstępnego $\mathrm{E}=0,8 \mathrm{~kJ} / \mathrm{mm}$ (lewa strona) i $\mathrm{E}=1,5$ $\mathrm{kJ} / \mathrm{mm}$ (prawa strona)

Fig. 7. Macrostructure in cross-section of welds with a length of 50 $\mathrm{mm}$ made of steel wire G1 8 on Armox 370T Class 2 without preheating $\mathrm{E}=0.8 \mathrm{~kJ} / \mathrm{mm}$ (left side) and $\mathrm{E}=1.5 \mathrm{~kJ} / \mathrm{mm}$ (right)

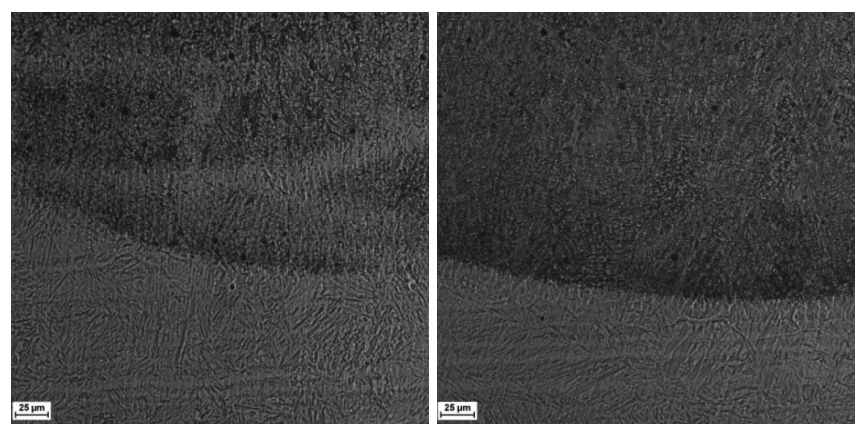

Rys. 8. Widok mikrostruktury $w$ obszarze linii stopienia napoin o długości $12.5 \mathrm{~mm}$, wykonanych metodą MAG na blasze ze stali Armox 370T Class 2, drutem SG2; bez podgrzewania (lewa strona) i z podgrzewaniem (prawa strona)

Fig. 8. View microstructure in the melt line welds with a length of $12.5 \mathrm{~mm}$, made of MAG on sheet steel Armox 370T Class 2, SG2 wire; without preheating (left side) and preheated (right)

\section{Badania metalograficzne napoin}

Z wykonanych próbek wykonano zgłady metalograficzne przekrojów poprzecznych napoin. Napoiny o długości 12,5 mm 
i $25 \mathrm{~mm}$ przecięto $\mathrm{w}$ połowie ich długości, natomiast napoiny o długości $50 \mathrm{~mm}$ i $75 \mathrm{~mm}$ przecięto dwukrotnie w 1/3 i 2/3 długości napoin. Wybrane widoki makroskopowe przekrojów poprzecznych napoin przedstawiono na rysunkach $4 \div 7$. Wyniki badań metalograficznych mikroskopowych w obszarze linii stopienia i strefy wpływu ciepła, dla wybranych próbek przedstawiono na rysunkach $8 \div 11$.

\section{Badania twardości wykonanych napoin}

Pomiary twardości HV1 wykonano na przekrojach poprzecznych napoin, w osi symetrii napoiny i wzdłuż linii równoległej do powierzchni blachy, rysunek 12. Przyjmując dla uproszczenia płaski przepływ ciepła w płaszczyźnie pomiaru twardości można przyjąć, że wzdłuż linii równoległej do powierzchni ciepło rozchodzi się w dwóch kierunkach, natomiast wzdłuż linii pionowej ciepło rozchodzi się tylko w jednym kierunku, więc wzrost twardości w miarę oddalania się od osi napoiny powinien być szybszy.

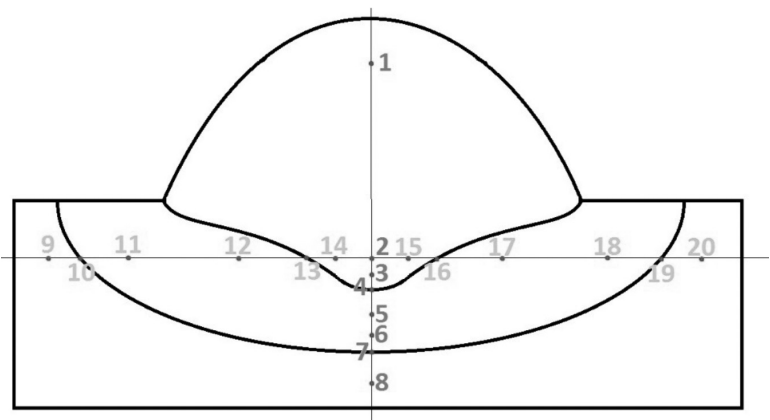

Rys. 12. Rozkład punktów pomiaru twardości w przekroju poprzecznym wykonanych napoin

Fig. 12. The plan of hardness measurement in cross-section of made tack welds
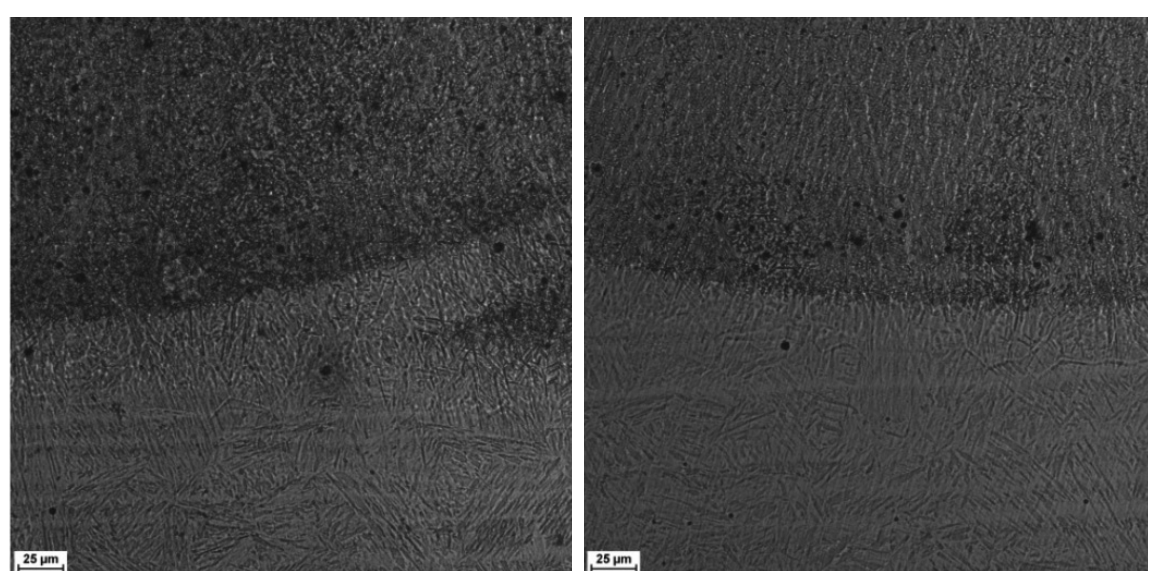

Rys. 9. Widok mikrostruktury w obszarze linii stopienia napoin o długości $75 \mathrm{~mm}$, wykonanych metodą MAG na blasze ze stali Armox 370T Class 2, drutem SG2; bez podgrzewania wstępnego (lewa strona) i z podgrzewaniem wstępnym (prawa strona)

Fig. 9. View microstructure in the melt line welds with a length of $75 \mathrm{~mm}$, made of MAG on sheet steel Armox 370T Class 2, SG2 wire; without preheating (left side) and preheated (right)
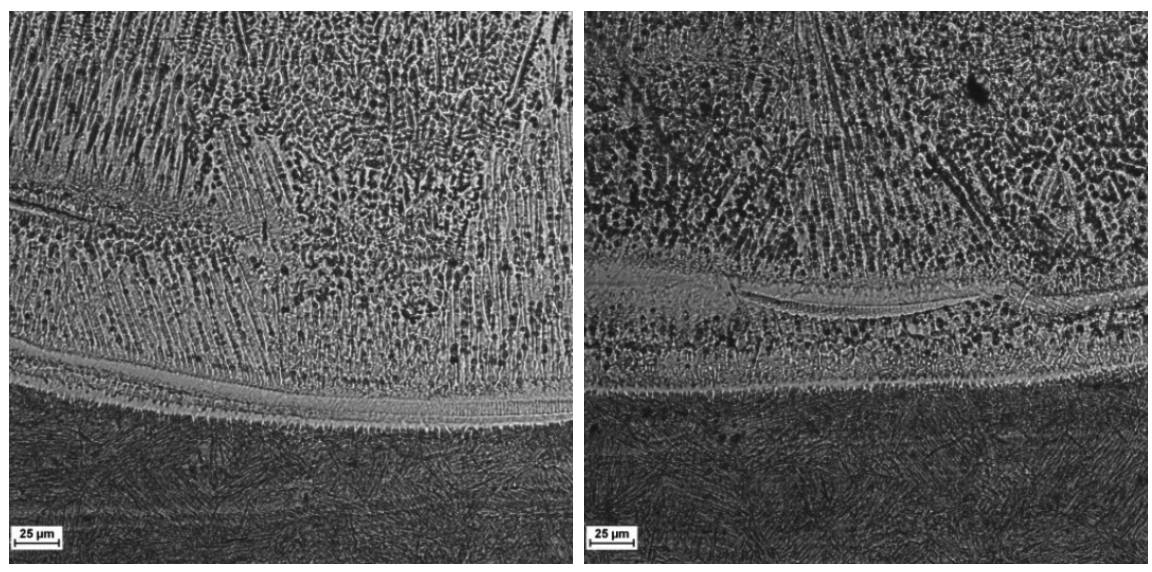

Rys. 10. Widokmikrostrukturynapoin odługości $12,5 \mathrm{~mm}$, wykonanych metodą MAG na blasze Armox 370T Class 2, drutem G18 8 Mn bez podgrzewania wstępnego energią liniową $\mathrm{E}=0,8 \mathrm{~kJ} / \mathrm{mm}$ (lewa strona) i $\mathrm{E}=1,5 \mathrm{~kJ} / \mathrm{mm}$ (prawa strona)

Fig. 10. View the microstructure of welds with a length of $12.5 \mathrm{~mm}$, made of MAG on sheet Armox 370T Class 2, wire G18 $8 \mathrm{Mn}$ without preheating heat input of $E=0.8 \mathrm{~kJ} / \mathrm{mm}$ (left side) and $\mathrm{E}=1.5 \mathrm{~kJ} / \mathrm{mm}$ (right side)
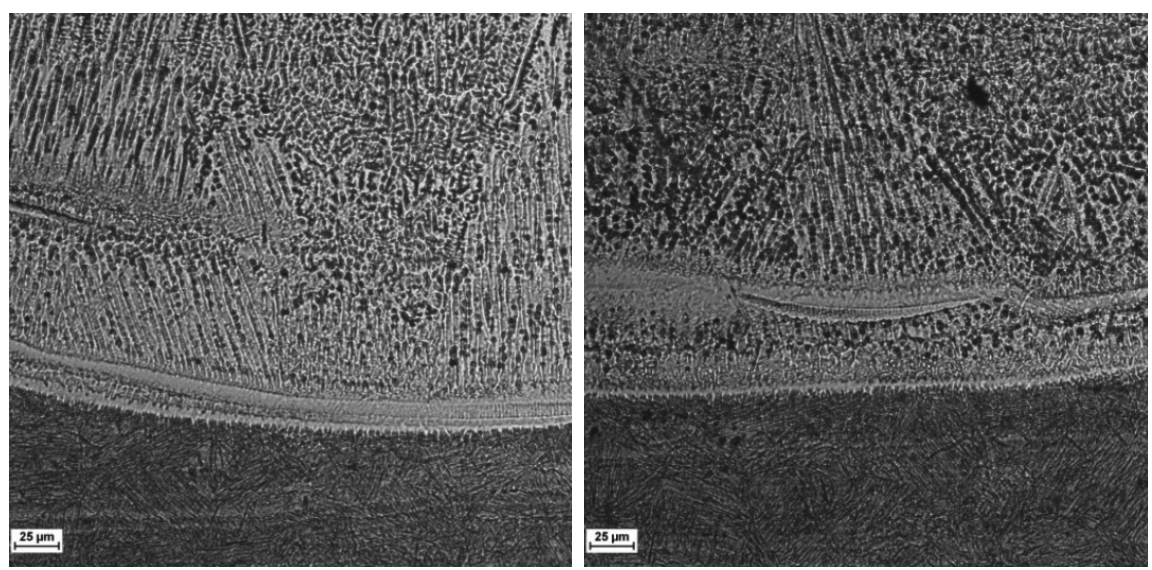

Rys. 11. Widok mikrostruktury napoin o długości $50 \mathrm{~mm}$, wykonanych metodą MAG na blasze Armox 370T Class 2, drutem G18 8 $\mathrm{Mn}$ bez podgrzewania wstępnego energią liniową $E=0,8 \mathrm{~kJ} / \mathrm{mm}$ (lewa strona) i $E=1,5 \mathrm{~kJ} /$ $\mathrm{mm}$ (prawa strona)

Fig. 11. View the microstructure of welds with a length of $50 \mathrm{~mm}$, made of MAG on sheet Armox 370T Class 2, wire G18 $8 \mathrm{Mn}$ without preheating heat input of $E=0.8 \mathrm{~kJ} / \mathrm{mm}$ (left side) and $\mathrm{E}=1.5 \mathrm{~kJ} / \mathrm{mm}$ (right side) 


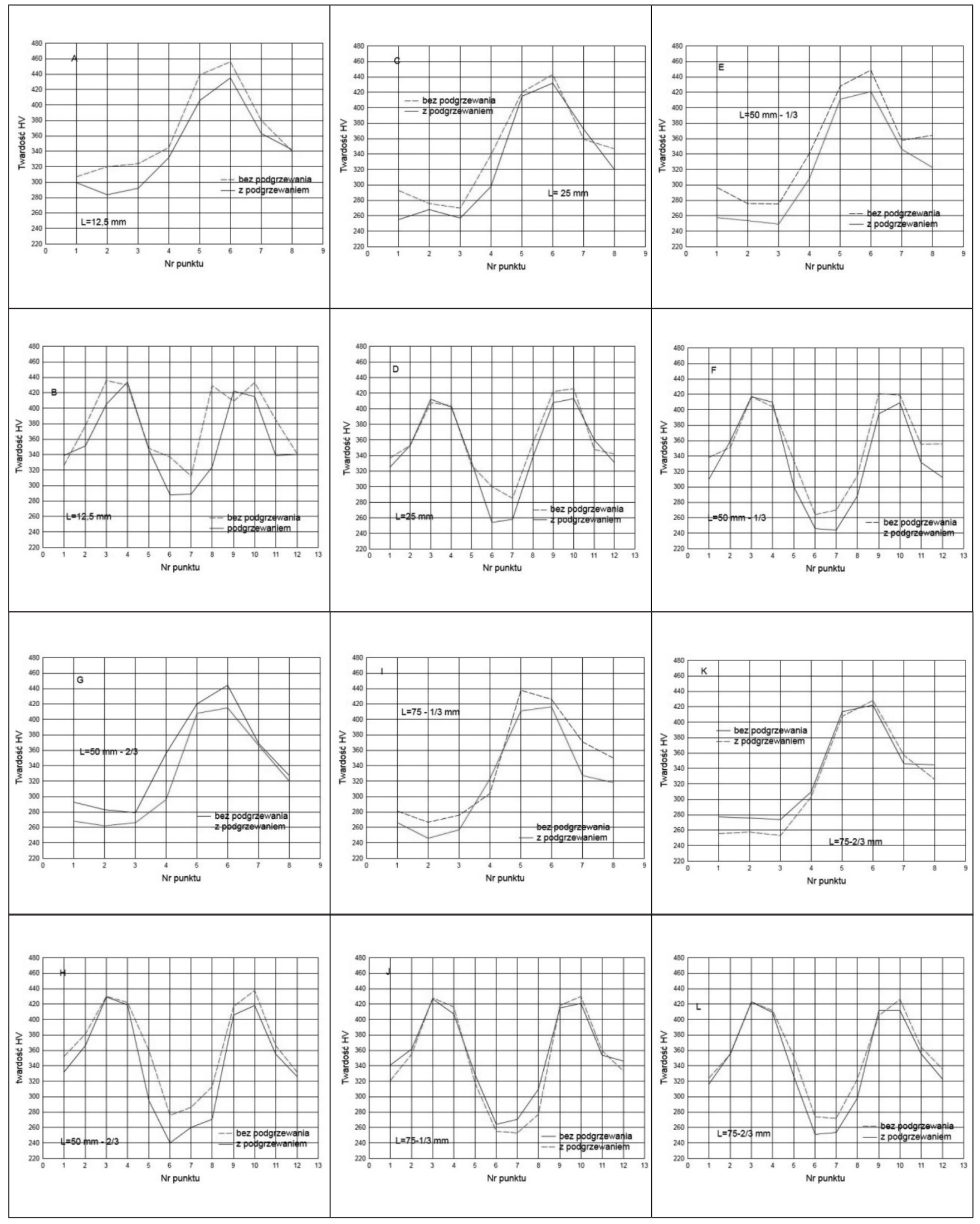

Rys. 13. Wpływ długości napoiny i podgrzewania wstępnego na rozkład twardości wzdłuż pionowej i poziomej linii pomiarowej (rys. 12) w obszarze napoiny wykonanej drutem SG2 na stali ARMOX 370T Class 2 . L - długość napoiny; 1/3, 2/3 - pomiar wykonany w 1/3 oraz 2/3 długości napoiny

Fig. 13. Effect of length of the weld and preheating for the distribution of hardness along the vertical and horizontal measurement line (fig. 12) in the area of weld made on steel ARMOX 370T Class 2 wire SG2. L - length of weld; 1/3, 2/3 measurement made in 1/3 or 2/3 of the length of the weld) 


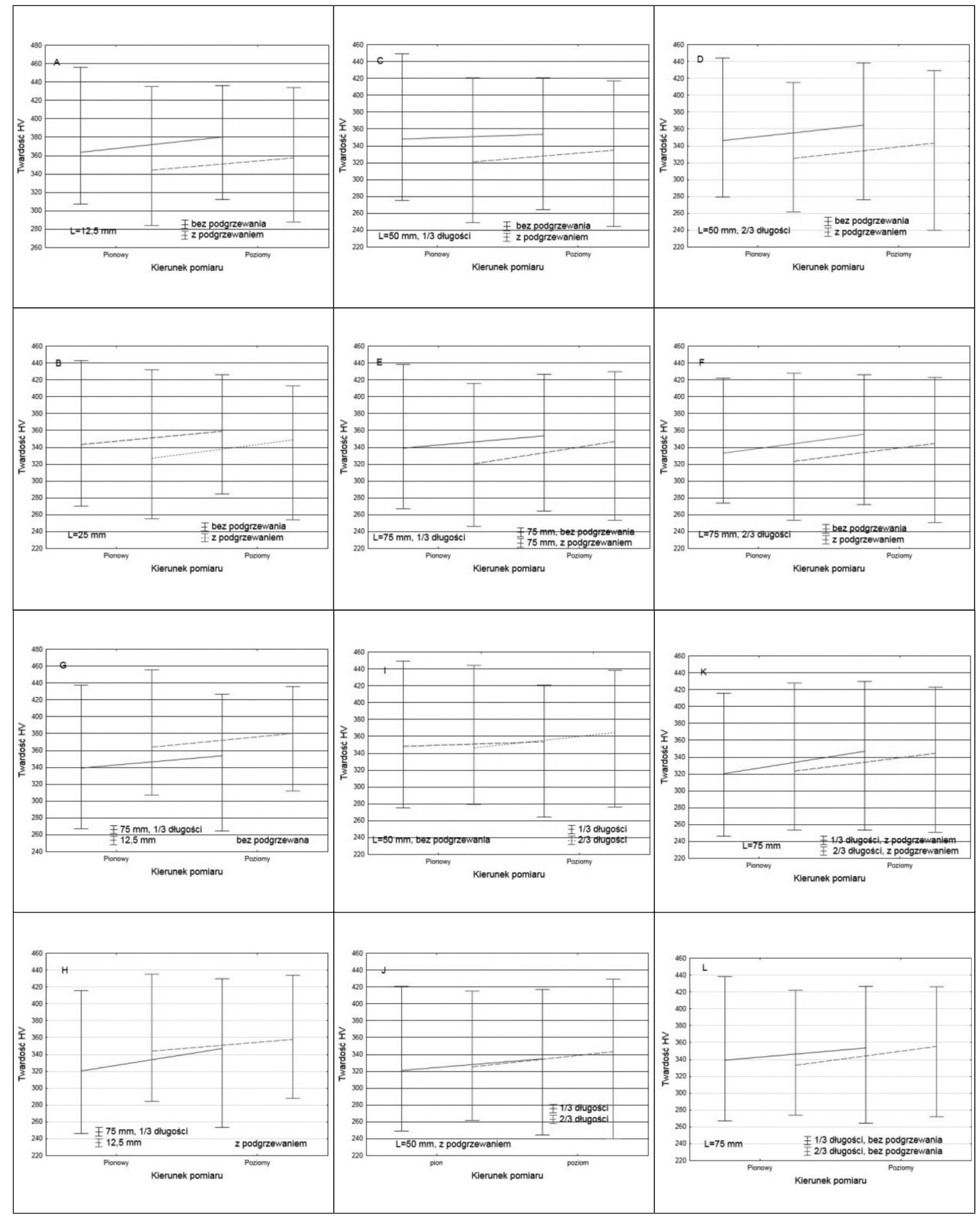

Rys. 14. Wpływ długości napoiny i podgrzewania wstępnego na wartość maksymalną, minimalną i średnią twardości wzdłuż pionowej i poziomej linii pomiarowej (rys. 12) w obszarze napoiny wykonanej drutem SG2 na stali ARMOX 370T Class 2. L - długość napoiny; 1/3, 2/3 pomiar wykonany w $1 / 3$ lub 2/3 długości napoiny

Fig. 14. Effect of length of the weld and preheating for the value of the maximum, minimum and average hardness along the vertical and horizontal measurement line (fig. 12) in the area of weld made on ARMOX 370T Class 2 steel wire SG2. L - length of the deposit; 1/3, $2 / 3$ measurement made $1 / 3$ or $2 / 3$ of the length of the weld 


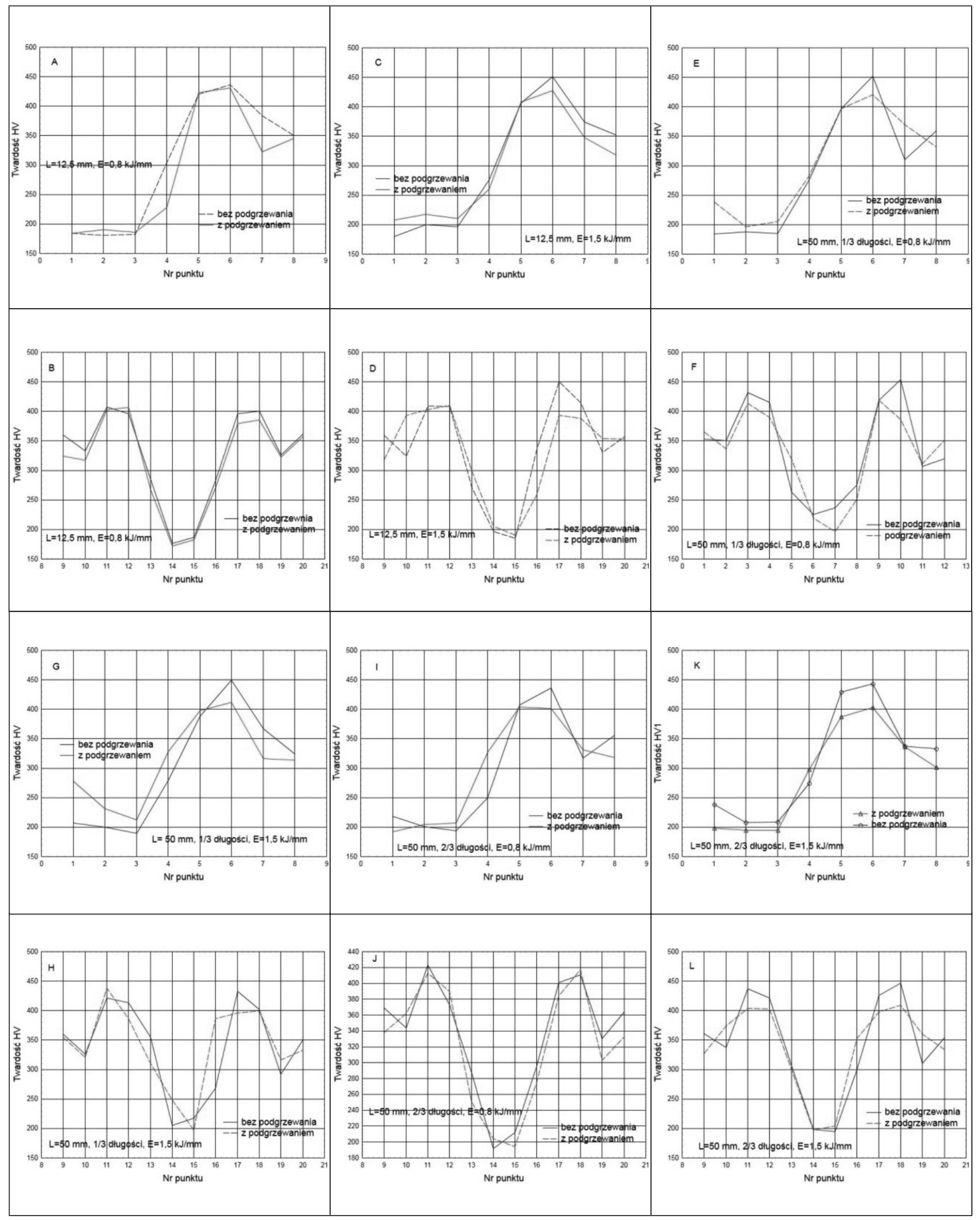

Rys. 15. Wpływ długości napoiny, podgrzewania wstępnego i energii liniowej łuku na rozkład twardości wzdłuż pionowej i poziomej linii pomiarowej (rys. 12) w obszarze napoiny wykonanej drutem G18 8 Mn na stali ARMOX 370T Class 2. L - długość napoiny; 1/3, 2/3 pomiar wykonany w $1 / 3$ lub $2 / 3$ długości napoiny

Fig. 15. Effect of length of the weld, preheating and heat input for the distribution of hardness along the vertical and horizontal measurement line (fig. 12) in the area of weld made on steel ARMOX 370T Class 2 wire G18 $8 \mathrm{Mn}$. L - length of weld; 1/3, 2/3 measurement made in 1/3 or $2 / 3$ of the length of the weld 


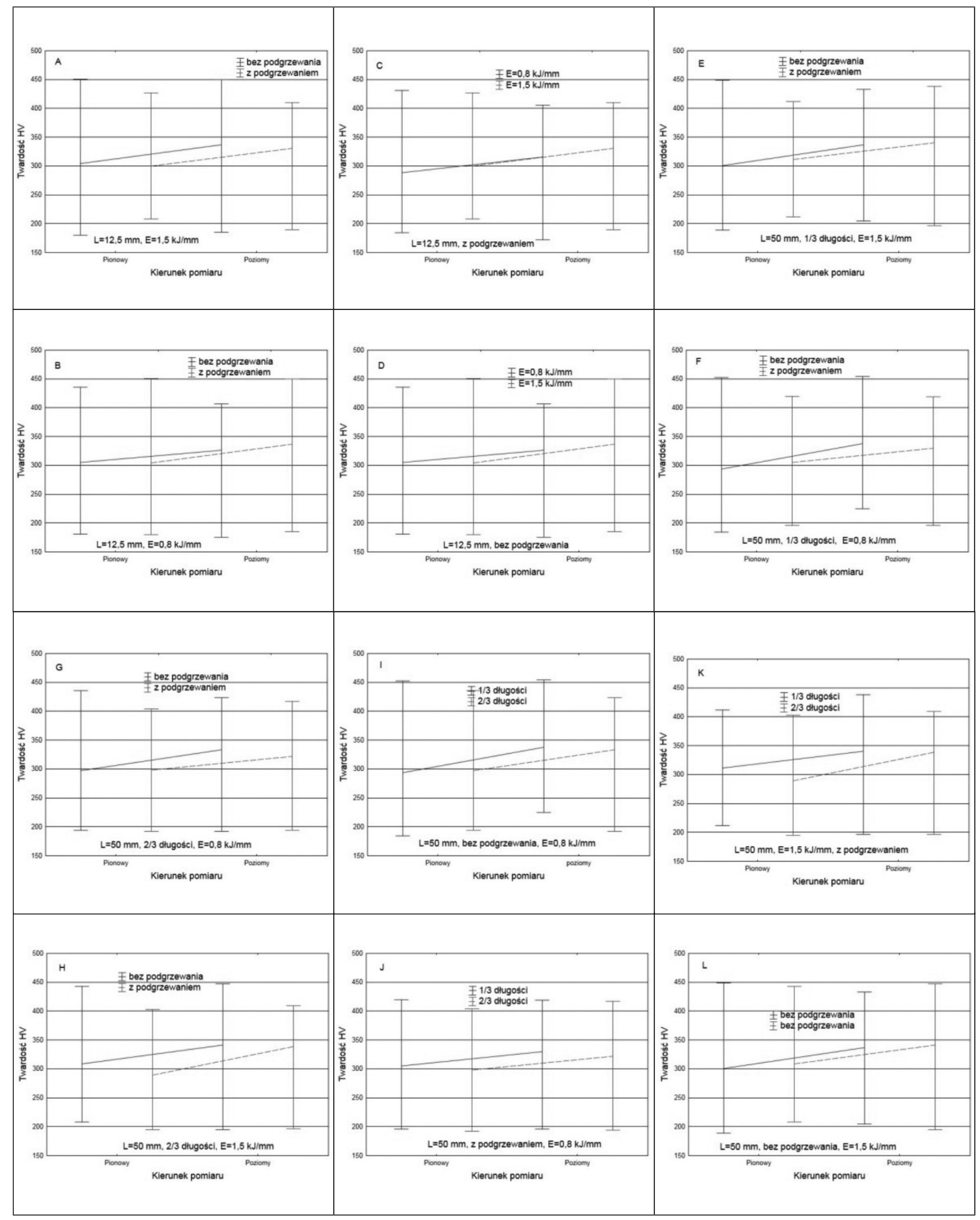

Rys. 16. Wpływ długości napoiny, podgrzewania wstępnego i energii liniowej łuku na rozkład twardości wzdłuż pionowej i poziomej linii pomiarowej (rys. 12) w obszarze napoiny wykonanej drutem G18 8 Mn na stali ARMOX 370T Class 2. L - długość napoiny; 1/3, 2/3 pomiar wykonany w $1 / 3$ lub $2 / 3$ długości napoiny

Fig. 16. Effect of length of the weld, preheating and heat input for the distribution of hardness along the vertical and horizontal measurement line (fig. 12) in the area of weld made on steel ARMOX 370T Class 2 wire G18 $8 \mathrm{Mn}$. L - length of weld; 1/3, 2/3 measurement made in 1/3 or $2 / 3$ of the length of the weld 


\section{Analiza wyników}

W artykule przedstawiono wyniki badań rozkładu twardości w obszarze napoiny wykonanej metodą MAG drutem przeznaczonym do spawania stali konstrukcyjnych (SG2) i drutem o składzie stali austenitycznej (G18 8 Mn) na materiale rodzimym o twardości $280 \div 330$ HV (ARMOX 370T Class 2). Połączenia tych materiałów występują przy wykonywaniu spoin sczepnych oraz przy mocowaniu elementów podzespołu do przyrządów montażowych i usztywniających. W zależności od warunków wykonania napoin możliwe jest uzyskanie w materiale rodzimym obszarów o zmniejszonej lub zwiększonej twardości, które pozostaną w konstrukcji i mogą wpływać na własności użytkowe pojazdów wykonanych z blach ARMOX. Wzrost twardości zmienionej w wyniku nagrzania ciepłem spawania struktury metalograficznej jest niekorzystny ze względu na możliwość zainicjowania w tym obszarze pęknięć w czasie eksploatacji pojazdu. Obniżenie twardości jest również niekorzystne, zwłaszcza na zewnętrznych powierzchniach pojazdów specjalnych, z uwagi na obniżenie ich odporności balistycznej. Badania przeprowadzono na blachach o grubości 14 mm zmieniając warunki wykonania napoin, rysunek 1: temperaturę podgrzewania, materiał dodatkowy, energię liniową spawania oraz długość napoiny. W napoinach o długości 50 i 75 mm twardość mierzono w dwóch przekrojach 1/3 i 2/3 długości napoiny. Ponieważ względem punktu leżącego w osi jeziorka spawalniczego ciepło rozchodzi w 2 kierunkach względem osi symetrii napoiny, a w jednym kierunku względem powierzchni blachy twardość także mierzono w dwóch kierunkach (rys. 12).

Analizując przedstawione widoki makroskopowe przekrojów poprzecznych obserwuje się zwiększoną szerokość

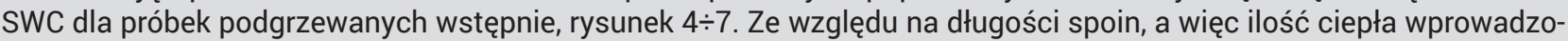
nego w obszar spoiny, wtopienie jest najmniejsze dla spoin krótkich o długości 12,5 mm, największe zaś dla spoin o dłu-

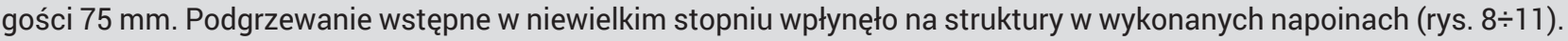

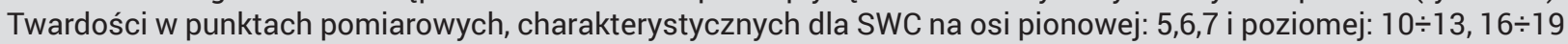
są największe dla wszystkich próbek. Obszary określone tymi punktami chłodzą się najszybciej, stąd duży wzrost twardości. Jednak jest on zależny również od ilości ciepła wprowadzonego do złącza, a więc częściowo od długości spoiny. Stąd najwyższa twardość występuje w obszarze spoin o małej długości wykonanych bez zastosowania podgrzewania wstępnego, rysunek 13 $\div 16$. Wyniki próbek z podgrzewaniem wstępnym wykazało obniżone twardości w SWC. Spoiny wykonane dużą energią liniową cechują się dużą twardością w SWC, nawet 450HV1. Spoiny o długości $75 \mathrm{~mm}$ wykazały najmniejsze twardości we wszystkich strefach. Rodzaj drutu wpływa nieznacznie na twardość SWC

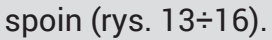

Uwzględniając wszystkie wyniki i na ich podstawie otrzymane zależności, jako minimalną długość spoin sczepnych można uznać długość $25 \mathrm{~mm}$ ze względu na najmniejszą twardości strefy przegrzania złącza. Ponadto stwierdzono, że napoiny należy wykonywać możliwie małą energią liniową spawania oraz w miarę możliwości zastosować podgrzewanie wstępne do możliwie najwyższej temperatury, przy której nie ulegają zmianie własności blach, jeżeli zaleca je producent.

\section{Literatura}

[1] L.Kuzmikova, H.Norrish, J.Pan: „Development of safe optimized weIding procedures for high strength Q\&T steel welded with austenitic consumalbes". Revista Soldagem e Inspecao, nr 18 (2), 2013, str. $169 \div 175$.

[2] I.Barenyi, O.Hires, P.Liptak: „Degradation of mechanical properties of armored steels after its welding". Materiały konferencyjne International Conference of Scientific Paper Afases, Brasov, 26-28 maj, 2011, str. $845 \div 848$.

[3] I.Barenyi, O.Hires, P.Liptak: „Over tempering of Armox armored steels at after secondary processing". Materiały konferencyjne International Conference of Scientific Paper Afases, Brasov, 24-26 maj, 2012.

[4] R.Willms: „High strength steel for constructions". Materiały konferencyjne Nordic Steel Construction Conference, 2-4 października, Malmo, Szwecja 2009.

[5] F.Schroter, T.Lehnert: „Trends in the application of high-performance steel in European bridge building". Materiały konferencyjne The Eight International Conference Bridges in Danube Basin, 2013, str. 35 $\div 50$.

[6] E.Brezova, H.Masiar, P.Radic: "Welding of high strength materials used in the manufacture special equipment". University Review, tom 8, nr 3-4, 2014, str. $51 \div 61$.

[7] G.Magudeeswaran, V.Balasubramanian, R.G.Madhusudhan: „Hydrogen induced cold cracking studies on armour grade high strength, quenched and tempered steel weldments", International Journal of Hydrogen Energy $33 / 2008$, str. $1897 \div 1908$.
[8] SSAB, Inc.: „Armox Protection Plate. Workshop Recommendations” [online]. [Dostępny 25 stycznia 2015]. Dostępny w internecie: http:// www.ssab.com/Global/Armox/Brochures/en/701-Armox_Workshop\%20recommendations.pdf.

[9] M.Gaspar, A.Balogh: „GMAW Experiments for advanced Q+T high strength steels", Production Processes and Systems, tom 6, nr 1 , 2013 , str. $9 \div 24$

[10] K.Hakansson: „Weld Metal Properties for Extra High Strength Steels”. Praca Doktorska, ISSN 1650 - 1888, Division of Welding; Department of Production Engineering; The Royal Institute of Technology, sierpień 2002.

[11] Ryszard Karcz, Sławomir Kwiecień, Marian Godniak, Ryszard Jastrzębski „Spawanie stali wysokowytrzymałych cz. II” Projektowanie i konstrukcje inżynierskie, nr 9, 2013.12.

[12] PN-EN 10025:6+A1:2009: „Wyroby walcowane na gorąco ze stali konstrukcyjnych - Część 6:Warunki techniczne dostawy wyrobów płaskich o podwyższonej granicy plastyczności w stanie ulepszonym cieplnie".

[13] SSAB, Inc.: „Armox 370T Protection Plate” [online]. [dostęp 25 stycznia 2015]. Dostępny w internecie: http://www.ssab.com/en/Brands/ Armox/Products/Armox-370T-Class-2/\#

[14] D.Schroepfer, A.Kromm, T.Kannengiesser. „Improving welding stresses by filler metal and heat control selection in component related butt joints of high strength steel". Welding in the World, styczeń 2015. 